\title{
Motile aeromonad septicemia (MAS) at Cyprinus carpio L., 1758 (Actinopterygii:Cyprinidae) in Lake Tödürge (Sivas/Turkey)
}

\author{
[Septicemia móvel por aeromonada (SMA) em Cyprinus carpio L., 1758 \\ (Actinopterygii: Cyprinidae) no lago Tödürge (Sivas, Turquia)] \\ B. Ünver, M.Z. Bakıcı
}

Sivas Cumhuriyet University - Sivas, Turkey

\begin{abstract}
In this study, fish's morphologic and anatomic lesions caused by motile aeromonad septicemia (MAS) depending on environmental stress in carp, Cyprinus carpio population living in Lake Tödürge were identified. Various morphological and anatomical deformations and lesions were observed in the body of approximately $17 \%$ (252 fish specimens) of a total of 1488 carp samples. Bacteria are grown from all wipe samples. Bacterial colonies have a gray-white appearance with round, convex and smooth edges. 15-20 cfu colonies were observed in each aerop culture. As a result of analysis of wet wipe samples from infected fish's skin, gill, kidney and liver, it is determined that the bacteria which causes septicemia is Aeromonas sobria from the Aeromonadaceae family (with $99.2 \%$ confidence value). No bacteria were grown in cultures except A. sobria. Some symptoms of the infection are inflammation on different parts of the fish bodies, eruption on skin and scales, dermal necrosis, degeneration at soft rays of the fins, exophthalmos, and purulent liquid accumulation in the abdominal cavity, etc. Infected fish were most commonly encountered in July and August (water temperature above $20^{\circ} \mathrm{C}$ ), the lowest in October and November (water temperature below $10^{\circ} \mathrm{C}$ ).
\end{abstract}

Keywords: environmental stress, Aeromonas sobria, motile aeromonad septicemia, Lake Tödürge, Turkey

\section{RESUMO}

Neste estudo, foram identificadas lesões morfológicas e anatômicas causadas por septicemia móvel por aeromônios (MPA), dependendo do estresse ambiental da carpa, a população de Cyprinus carpio que vive no lago Tödürge foi identificada. Várias deformações e lesões morfológicas e anatômicas foram observadas no corpo de aproximadamente 17\% (252 amostras de peixes) de um total de 1488 amostras de carpa. As bactérias são cultivadas a partir de todas as amostras de limpeza. As colônias bacterianas têm uma aparência branco-acinzentada, com bordas arredondadas, convexas e lisas. Foram observadas 15 20 colônias de UFC em cada cultura de aerop. Como resultado da análise de amostras de lenços umedecidos da pele, brânquias, rins e fígado de peixes infectados, é determinado que a bactéria que causa a septicemia é a Aeromonas sobria, da família Aeromonadaceae (com valor de confiança de 99,2\%). Nenhuma bactéria foi cultivada em culturas, exceto A. sobria. Alguns sintomas da infecção são inflamação em diferentes partes dos corpos dos peixes, erupção na pele e escamas, necrose dérmica, degeneração aos raios moles das barbatanas, exoftalmia e acúmulo de líquido purulento na cavidade abdominal, entre outros. Os peixes infectados eram encontrados com maior frequência em julho e agosto (temperatura da água acima de $20^{\circ} \mathrm{C}$ ), e eram menos comumente encontrados em outubro e novembro (temperatura da água abaixo de $10^{\circ} \mathrm{C}$ ).

Palavras-chave: estresse ambiental, Aeromonas sobria, septicemia móvel por aeromônios, lago Tödürge, Turquia

Recebido em 31 de março de 2020

Aceito em 27 de outubro de 2020

E-mail: bunver@cumhuriyet.edu.tr 


\section{INTRODUCTION}

Bacterial infections, caused by motile members of the genus Aeromonas, are among the most common and troublesome diseases in fish raised in ponds and recirculating systems (Camus et al., 1988). Beaz-Hidalgo and Figueras (2013) have also stated that Aeromonas spp. are important fish pathogens and are a persistent threat to the aquaculture sector. The wide-spread distribution of these bacteria in the aquatic environment and the stress induced by intensive culture practices predisposes fish to infections. Motile aeromonad infections have been recognized for many years and have been referred to by various names, including motile aeromonad septicemia (MAS), motile aeromonad infection (MAI), and hemorrhagic septicemia (HS). Whether acting alone or in mixed infections with other organisms, the motile aeromonads are responsible for significant financial losses annually. All species of fish, scaled or unscaled, are susceptible to infection. Under certain conditions, mortalities can approach 100 percent (Camus et al., 1988). In many cases, infections caused by mesophilic motile Aeromonas species show pathological lesions that may only be seen in the skin or internal organs. Motile aeromonad septicemia is a clear example of a stress-induced disease that affects freshwater fish (Figueras et al., 2011; Beaz-Hidalgo and Figueras, 2012; Kozinska and Pekala, 2012).

Natural habitats of the Aeromonas group bacteria are aquatic environments. It has been identified that these bacteria are in the fresh waters, brackish waters and sea waters, fish production pools, soil, natural spring waters, lentic systems, sewage waters, both unchlorinated and chlorinated water supplies (Kandil, 1976; Çolak, 1982; Araoju et al., 1991; Akan, 1993; Marcel et al., 2002; Timur and Timur, 2003; Janda and Abbott, 2010; Ashiru et al., 2011).

Several investigations have shown that members of the genus Aeromonas are also widely distributed in various foods such as vegetables, meat, fish and chicken. Thus, foods have been suggested as a vector in the dissemination of this pathogen (Radu et al., 2003; Janda and Abbott, 2010). Aeromonas group bacteria from the Aeromonadaceae family are opportunistic pathogen microorganisms in the humans and amphibians, turtles and crocodiles from cold blooded organisms and especially in fish and in conditions of stress, such as an increase in water temperature, poor water quality, excessive handling, etc., they are major cause for epidemic outbreaks (Akan, 1993; Merino et al., 1995; Timur and Timur, 2003; Noga, 2010; BeazHidalgo and Figueras, 2012, 2013). Virulence of Aeromonas spp. is multifactorial and not completely understood (Pablos et al., 2009). Among these, Aeromonas hydrophila, Aeromonas caviae and Aeromonas sobria are motile and they are agents of two important disease groups in humans such as septicemia and gastroenteritis (Austin and Austin Allen, 1985; Janda, 1991; Merino et al., 1995; Kapetanovic et al., 2005; Beaz-Hidalgo and Figueras, 2013). It is known that bacteria isolated from freshwater fish are mostly in the Aeromonas group (Austin and Austin Allen, 1985; Kapetanovic et al., 2005) and these bacteria increase in freshwater lakes in summer months (Rippey and Cabelli; 1989).

A. sobria is classified as facultative anaerobic rod and gram-negative bacteria. This bacterium with mesophilic character are motile employing a single-polar flagellum. Depending on stress, it can cause various infections in fish with weak immune systems (Kandil, 1976; Akan, 1993; Harikrishnana and Balasundaram, 2005; Majtan et al., 2012; Beaz-Hidalgo and Figueras, 2013). The lake consists of a great biodiversity especially economically the carp population takes an important place in fish fauna of the lake (Unver and Yildirim, 2011). In the course of fish sampling studies, carp samples with various wounds and deformations on their bodies were seen; some dead fish were also detected. In this study, morphological and anatomical damages seen in fish and the reasons for consequential deaths were analyzed.

\section{MATERIALS AND METHODS}

$39^{\circ} 53^{\prime}$ north and $37^{\circ} 36^{\prime}$ east coordinated lake (Zara-Sivas) is located in the Kizllirmak River Basin of Central Anatolia and about $56 \mathrm{~km}$ far away from the Sivas city center. Its altitude above sea level is $1295 \mathrm{~m}$ high and its surface area is 350 ha. Lake Tödürge is one of the largest karstic lakes in Turkey. The average depth of this shallow lake is 2 meters. C. carpio living in Tödürge has economic importance. They are intensively hunted by local people and fishermen. The ichthyofauna of the lake consists of eight fish 
species (Unver and Erk'akan, 2011; Unver and Yildirim, 2011)

For morphological and anatomical investigations, sixty carp samples with various wounds and deformations on their bodies were taken from the lake with gillnets and trammel nets with 10-32 $\mathrm{mm}$ mesh sizes. The fish caught were anesthetized with MS-222 solution ( $0.1 \mathrm{~g} / \mathrm{l})$ and brought to the laboratory in iceboxes. All fish samples were examined morphologically and anatomically. Besides their ages and sexes were identified. Eight wipe samples were taken from skins, gills, kidneys and livers of the fish for bacteriological analyses. Preparations were made for gram staining from these wipes. For aerobe culture, placing was performed into 5\% sheep blood agar (Oxoid) and eosin-methylene blue (EMB) agar (Merck) mediums.

It was incubated for 48 hours in $36 \pm 1^{\circ} \mathrm{C}$ incubator. For anaerobic culture, placing was performed into anaerobe agar (Merck) and Schaedler agar (Acumedia) plate. It was incubated for 96 hours in $36 \pm 11^{\circ} \mathrm{C}$ incubator. Aerobic cultures were again checked after a day. Bacterial colonies growing on agar were identified using gram staining and API 20 NE (bioMérieux) biochemical test kits. Non-productive plates incubated one more day. Due to non-productive anaerob culture plates in four days of incubation, they incubated for another three days.

\section{RESULTS AND DISCUSSION}

A total of 1488 carp samples (652 male, 836 female) were obtained from the lake. Ages of the samples changed between I-VII years. Fork length ranged between 70-386 mm and body weight was between 13.0 and $966.2 \mathrm{~g}$. Various morphological and anatomical deformations and lesions were observed in 252 of 1488 carp sample, which corresponds to about $17 \%$. For morphological and anatomical investigations, 60 samples were selected from these fish. Eight wipe samples were taken from skins, gills, kidneys and livers of the fish for bacteriological analyses and preparations were prepared for gram staining. Bacteria are grown from all wipe samples. Bacterial colonies have a gray-white appearance with round, convex and smooth edges. 15-20 cfu colonies were observed in each aerop culture. Microscopic examination of these bacteria colonies revealed that the colonies consisted of gram (-) bacilli.
When the bacteria were identified from these gram (-) bacterial colonies with the API $20 \mathrm{NE}$ (bioMérieux) biochemical test kits, with $99.2 \%$ confidence value, it was detected that the bacteria named Aeromonas sobria causes various morphological and anatomical deformations and inflammation in fish as seen from Table 1. No bacteria were grown in cultures except $A$. sobria. It was determined that fish deaths were caused by motile aeromonad septicemia (MAS). All symptoms of the infection are seen in almost each age group and they are more common and severe in individuals older than III. The majority of the dead fish are the individuals older than VII. There was no difference between sexes in terms of incidence frequency and severity of the infection. Infected fish were frequently seen when the lake water's temperature is over $20{ }^{\circ} \mathrm{C}$ in July and August. Fish deaths reached also a peak in these months. Infected fish were rarely seen in Autumn (in October and November) with decreasing of the water degree above $10^{\circ} \mathrm{C}$.

Motile aeromonad septicemia was seen only in carp samples. No signs of infection were detected in the other 7 fish species living in the lake. Motile Aeromonas species (A. hydrophila, A. sobria, and A. caviae) are one of the most common bacteria types in freshwater ecosystems (Austin and Austin Allen, 1985; Kapetanovic et al., 2005; Beaz-Hidalgo and Figueras, 2013). The wellestablished method for manual microorganism identification to the species level, bioMérieux's API identification products are test kits for identification of gram (+) and gram (-) bacteria. As a result of bacteriological analyses of wipe samples taken from carps living in Lake Tödürge, A. sobria type bacteria were isolated (API $20 \mathrm{NE}$; with $99.2 \%$ confidence value).

A. sobria is a facultative anaerobic and gramnegative bacterium. This bacterium with mesophilic character are motile by means of a single-polar flagellum. Aeromonas have two types of flagella (polar and lateral) responsible for their motility. Recent studies have demonstrated that all motile Aeromonas species produce a single polar flagellum, which allows the bacteria to swim through a liquid environment (Canals et al., 2007; Wihelms et al., 2009). It is known that A. sobria, an opportunistic pathogen, can cause various infections depending on stress in fish whose immune systems are weak. 
Table 1. Biochemical characterization of Aeromonas sobria isolated from infected carp specimens (API 20 NE; biochemical test)

\begin{tabular}{|c|c|}
\hline \multicolumn{2}{|c|}{$\begin{array}{l}\text { Reference: } 19152 \\
\text { Very good identification }\end{array}$} \\
\hline \multicolumn{2}{|c|}{ Strip: API 20 NE V6.0 } \\
\hline \multicolumn{2}{|c|}{ Profile: 7176755} \\
\hline \multicolumn{2}{|c|}{$\begin{array}{c}\text { NO3+ TRP+ GLU+ ADH+ URE- ESC- GEL- PNPG+ GLUa+ ARAa- MNEa+ } \\
\text { MANa+ NAGa+ MALa+ GNTa+ CAPa+ ADIa- MLTa+ CITa+ PACa- OX+ }\end{array}$} \\
\hline Significant rate & Tests against \\
\hline Aeromonas sobria & 1.00 \\
\hline $\begin{array}{l}\text { Next choice } \\
\text { Aer. hydro./caviae }\end{array}$ & 0.72 \\
\hline \multicolumn{2}{|c|}{ ID. Not valid before 48 -h incubation! } \\
\hline \multicolumn{2}{|c|}{ Aeromonas sobria: $\quad 0$ test (s) against } \\
\hline \multicolumn{2}{|c|}{ Next choice } \\
\hline Aer. hydro./caviae: & 2 test $(\mathrm{s})$ against \\
\hline Esculine (Hydrolyse) (Esc) $89 \%$ & L-arabinose (assimilatio) (ARAa) $80 \%$ \\
\hline
\end{tabular}

Stress in particular is the major reason for increased sensitivity of the fish against the bacteria (Kandil, 1976; Akan, 1993; Harikrishnana and Balasundaram, 2005; Noga, 2010; Figueras et al., 2011; Beaz-Hidalgo and Figueras, 2012, 2013). Environmental stress factors, particularly those associated with poor water quality conditions, enhance the development of disease. These factors include high water temperatures, high ammonia and nitrite levels, $\mathrm{pH}$ disturbances, and low dissolved oxygen levels (Camus et al., 1988; Noga, 2010; Figueras et al., 2011; Beaz-Hidalgo and Figueras, 2012, 2013). An intensive culture system and poor physiological and environmental conditions make the fish susceptible to diseases (Couch, 1975; Noga, 2010; Beaz-Hidalgo and Figueras, 2012, 2013). These stressors adversely alter the immune response of the fish (Snieszko and Bullock, 1976).

Lake Tödürge is a shallow and small lake. Its surface area and average depth is 350 ha and 2 meters, respectively (Unver and Erk'akan, 2011). Speedboat and jet-ski have been frequently being used with sportive purposes in spring and summer period (this period corresponds to reproduction period of $C$. carpio) for several years. These human activities caused high wave motions and sudden changes in the water level, noise, turbidity increase, decrease in dissolved oxygen level, increase in water temperature, less transparency of water and chemical pollution. These physical and chemical changes both have restricted living areas of carp specimens in shallow and small Lake Tödürge and adversely affected feeding and reproduction activities. It caused stress and accordingly caused decreasing in immune functioning in fish. The reason for the motile aeromonad septicemia seen in $C$. carpio population is being considered as negative results of these anthropogenic activities.

Aeromonas outbreaks are usually seasonal, with peaks in the spring to early summer and in the fall when water temperatures are between 18 to $29^{\circ} \mathrm{C}$. Spring outbreaks may be related to decreased disease resistance in fish that are in poor condition from overwintering or after spawning (Camus et al., 1988). Similarly, Rippey and Cabelli (1989) state that Aeromonas group bacteria increase in freshwater lakes in summer months. The incidence of the disease appears related to environmental factors (Noga, 2010; Beaz-Hidalgo and Figueras, 2012, 2013). Meyer, studying seasonal fluctuations in the incidence of disease on fish farms, noted that the infection incidence peaked in April and August and remained highest during the summer months (Ribelin and Migaki, 1975). In the presented study, infected carp samples and dead fish were mostly seen in July and August when lake water is above $20^{\circ} \mathrm{C}$.

Motile aeromonad septicemia occurs as an acute or chronic or latent infection (Cipriano et al., 1984; Kozinska and Pekala, 2012; Beaz-Hidalgo and Figueras, 2013). In the chronic form, dermal ulceration and muscle necrosis are the most prominent symptoms (Bullock et al., 1971). Physical and behavioral symptoms of the Aeromonas infections are various. Lesions have 
been reported in skin, muscle, liver, intestine, heart, spleen, and pancreas. There are small bleedings on fish skin and fin bases, swollen abdomen and prominent eyes in infected fish. Fluid accumulation in abdomen, swollen liver and spleen and water-filled intestines are internal symptoms (Kandil, 1976; Akan, 1993; Kozinska and Pekala, 2012; Beaz-Hidalgo and Figueras, 2013). All typical symptoms of the motile aeromonad septicemia were observed in carp's Lake Tödürge population.

Motile aeromonad septicemia's symptoms are seen in Figure 1 and Figure 2. Motile aeromonad septicemia caused by A. sobria emerges with inflammation on different parts of the fish bodies at the beginning. This hyperemia is common on fish's head region, cheeks, lower parts of operculum, and base parts of pectoral fins and was also partially observed on sides and abdomen region of the body (Figure 1a). In advanced stages, hyperemia spread to all parts of the body. Partially degeneration starts on skin and scales of the fish (Figure 1b). The epidermis and dermis then undergo necrosis. Necrosis was observed especially on predorsal region, between pectoral and pelvic fins (Figure 1c). At this stage of the infection, inflammation on fins and fin bases and wounds on the nose area of some fish specimens were determined (Figure 1d). Dermal ulceration spreads throughout the body and turns into deep crater-like wounds. This necrosis was irregularly seen particularly on sides of the body (Figure 1e).

Dermal ulcers were observed on the underside of the eye in some fish (Figure 2a). In advanced stages of the infection, it was detected that dermal necrosis turned into muscle necrosis and it reached vertebrae by deepening (Figure 2b). In some fish, anal fin branched rays were completely degenerated, whereas caudal fin branched rays were partially degenerated (Figure2c). Exophthalmus was detected in the eyes of the many fish (Figure 2d). At the last stage of the aeromonad septicemia, it was observed that the abdomen of the fish was swollen (Figure 2e). After an examination, a purulent liquid was found in the abdominal cavity.

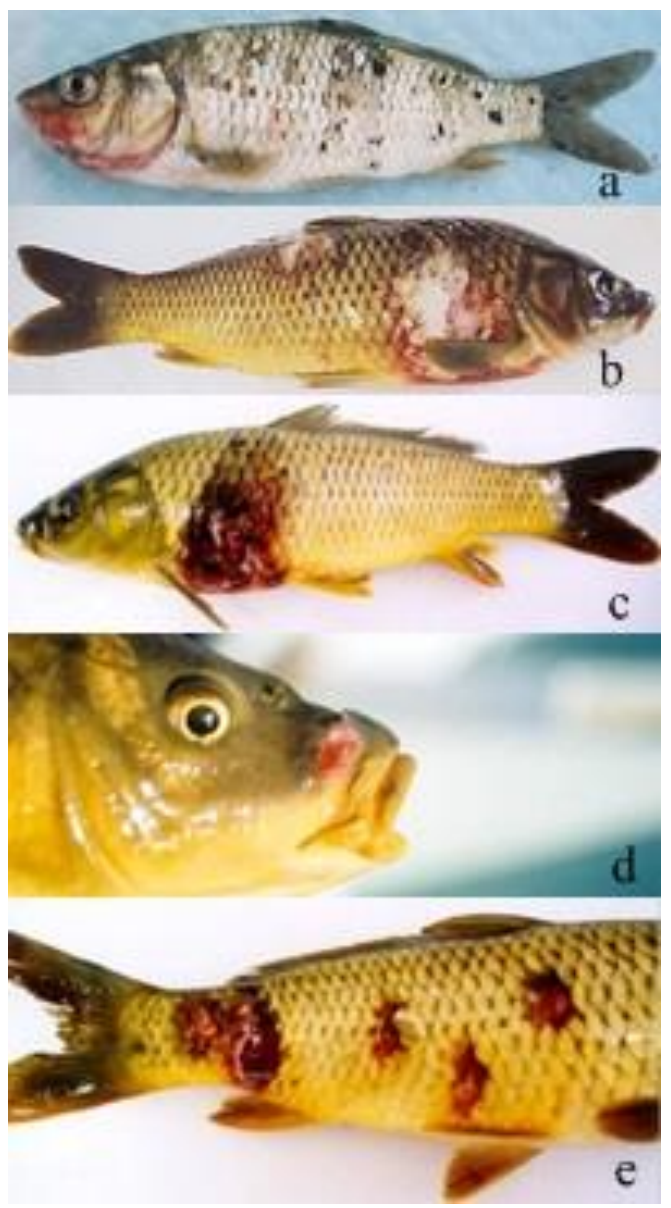

Figure 1. Morphological symptoms of motile aeromonad septicemia (MAS) in C. carpio (a-e).

Within this period, it was determined that fish movements slowed down, and fish had difficulty staying at a certain level in water vertically. Fish that reaching the final stage of the infection are generally located shoreline and die in a short time. Fish deaths were more seen in older ones (VII ages group and older). Dead fish were collected from the lake by means of a scoop net to reduce the prevalence of infection and buried in deep holes. Aeromonas infection never remains as a chronical problem. The important thing is determining the stress factor which weakens immune system of the fish against bacteria and removing it (Kandil, 1976; Akan, 1993; Noga, 2010; Beaz-Hidalgo and Figueras, 2012, 2013). 


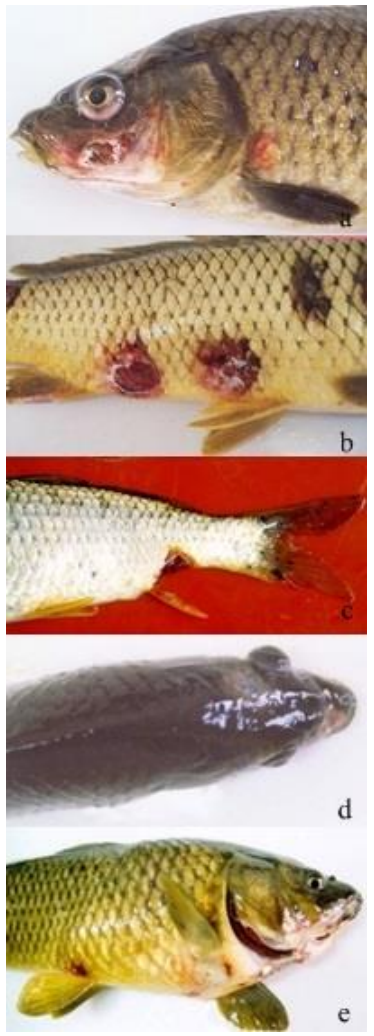

Figure 2. Morphological symptoms of motile aeromonad septicemia (MAS) in C. carpio (a-e).

\section{CONCLUSION}

It is believed that the cause of motile aeromonad septicemia in $C$. carpio population is the anthropogenic activities. All typical symptoms of the motile aeromonad septicemia were observed in Lake Tödürge.

\section{REFERENCES}

AKAN, M. Biochemical, toxigenic, enzymatic and cell surface properties of motile aeromonas species isolated from animals and environmental sources. 1993. Thesis (PhD) - Ankara University, Ankara, Turkey.

ARAOJU, R.M.; ARRIBAS, R.M.; PARES, R. Distribution of Aeromonas species in waters with different level of pollution. J. Appl. Bacteriol., v.71, p.182-186, 1991.

ASHIRU, A.W.; UABOI-EGBENI, P.O.; OGUNTOWO, J.E. et al. Isolation and Aeromonas species from Tilapia fish (Tilapia nilotica) and catfish (Clarias betrachus). Pak. J. Nutr., v.10, p.982-986, 2011.
AUSTIN, B.; AUSTIN ALLEN, D. Bacterial pathogens of fish. J. Appl. Bacteriol., v.58, p.483506, 1985.

BEAZ-HIDALGO, R.; FIGUERS, M.J. Molecular detection and characterization of furunculosis and other Aeromonas fish infections. Health Environ. Aquacul., p.97-132, 2012.

BEAZ-HIDALGO, R.; FIGUERS, M.J. Aeromonas spp. whole genomes and virulence factors implicated in fish disease. J. Fish Dis., v.36, p.371-388, 2013.

BULLOCK, G.L.; CONROY, D.A.; SNIESZKO, S.F. Bacterial diseases of fish. In: SNIESZKO, S.F.; AXELROD, H.R. (Eds.). Disease of fishes. Neuptune, New Jersey: T.F.H. Publications, 1971.

CAMUS, A.C.; DURBOROW, R.M.; HEMSTREET, W.G. et al. Aeromonas bacterial infections- motile aeromonad septicemia. SRAC Public., no. 478, p.1-4, 1988.

CANALS, R.; VILCHES, S.; WILHELMS, M. et al. Nonstructural flagella genes affecting both polar and lateral flagella-mediated motility in Aeromonas hydrophila. Microbiology, v.153, p.1165-1175, 2007.

CIPRIANO, R.C.; BULLOCK, G.L.; PYLE, S.W. Aeromonas hydrophila and motile aeromonad septicemia of fish. U.S. Fish and Wildfish Service, Fish Diseases, 1984, Leaflet 68.

COUCH, J.A. Histopathological effects of pesticides and related chemicals on the livers of fishes. In: RIBELIN, W.E.; MIGAKI, G, (Eds.). The pathology of fishes. Madision: University of Wisconsin Press, 1975, p.559-584.

ÇOLAK, A. Handbook of fish diseases. Sivas: Cumhuriyet Univ. Publications, 1982.

FIGUERAS, M.J.; BEAZ-HIDALGO, R.; COLLADO, L. et al. Point of view on the recommendations for new bacterial species description and their impact on the genus Aeromonas and Arcobacter. Bull. Bergey's Int. $S^{o}$ Ciety Microbial. Syst., v.2, p.1-16, 2011.

HARIKRISSHNANA, R.; BALASUNDARAM, C. Modern trends in Aeromonas hydrophila disease management with fish. Rev. Fish Sci., v.13, p.281-320, 2005. 
JANDA, J.M.; ABBOTT, S.L. The genus Aeromonas, taxonomy, pathogenicity, and infection. Clinic. Microbiol. Rev., v.23, p.35-73, 2010.

JANDA, J.M. Recent advances in the study of the taxonomy, pathogenicity and infections syndromes ass Ciated with the genus Aeromonas. Clinic. Microbiol. Rev., v.4, p.397-410, 1991.

KANDIL, M. Fish diseases. Ankara: Firat University Veterinary Faculty, 1976. (Publications n.5).

KAPETONOVIC, D.; KURTOVIC, B.; TESKEREDZIC, E. Differences in bacterial population in rainbow trout (Oncorhynchus mykiss Walbaum), fry after transfer from incubator to pools. Food Tech. Biotech., v.43, p.189-193, 2005.

KOZINSKA, A.; PEKALA, A. Characteristics of disease spectrum in relation to species, serogroups, and adhesion ability of motile aeromonads in fish. Sci. World J., v.2012, p.1-9, 2012.

MAJTAN, J.; CERNY, J.; OFUKANA, A. et al. Mortality of therapeutic fish Garra rufa caused by Aeromonas sobria. Asian Pac. J. Trop. Biomed., v.2, p.85-87, 2012.

MARCEL, K.A.; ANTOINETTE, A.A.; MIREILLEE, D. Isolation and characterization of Aeromonas species from an eutrophic tropical estuary. Mar. Poll. Bull., v.44, p.1341-1344, 2002.

MERINO, S.; RUBIRES, X.; KN ${ }^{\circ} \mathrm{CHEL}$, S. et al. Emerging pathogens: Aeromonas spp. Int. J. Food Microbiol., v.28, p.157-168, 1995.

NOGA, E.J. Fish diseases: diagnosis and treatment, 2.ed., Singapore: Wiley-Blackwell, 2010 .
PABLOS, M.; RODRIGUEZ-CALLEJA, J.M.; SANTOS, J.A. et al. Occurrence of motile Aeromonas in municipal drinking water and distribution of genes encoding virulence factors. Int. J Food Microbiol., v.135, p.158-164, 2009.

RADU, S.; AHMAD, N.; LING, F.H. et al. Prevalence and resistance to antibiotics for Aeromonas species from retail fish Malaysia. Int. J. Food Microbiol., v.81, p.261-266, 2003.

RIBELIN, W.E.; MIGAKI, G. The pathology of fishes. Wisconsin: Wisconsin Press 1975.

RIPPEY, S.R.; CABELLI, V.J. Use of thermotolerant Aeromonas group for the trophic classification of freshwaters. Water Res., v.23, p.1107-1114, 1989.

SNIESZKO, S.F.; BULL ${ }^{\circ}$ CK, G.L. Diseases of freshwater fishes caused by bacteria of the genera Aeromonas, Pseudomonas and Vibrio. Washington: Division of Cultural Methods Research / Department of Interior, 1976. 10p.

TIMUR, G.; TIMUR, M. Fish diseases. İstanbul: İstanbul University, 2003. (Publications n.5).

UNVER, B.; ERK'AKAN, F. Diet composition of chub, Squalius cephalus (Teleostei: Cyprinidae), in Lake Tödürge, Sivas, Turkey. J. Appl. Ichthyol., v.27, p.1350-1355, 2011.

UNVER, B.; YILDIRIM, M. Population characteristics of carp from Tödürge Lake in Sivas, Turkey. Int. J. Agric. Biol., v.13, p.935940, 2011.

WILHELMS, M.; VILCHES, S.; REYES, M. et al. Two redundant sodium-driven stator motor proteins are involved in Aeromonas hydrophila polar flagellum rotation. J. Bacteriol., v.191, p.2206-2217, 2009. 